\title{
Powder XRD, PSD and DSC Analysis of the Consciousness Energy Healing Treated Zinc Chloride
}

\section{Dahryn Trivedi ${ }^{1}$ and Snehasis Jana ${ }^{2 *}$}

${ }^{1}$ Trivedi Global, Inc., Henderson, USA

${ }^{2}$ Trivedi Science Research Laboratory Pvt. Ltd., Thane (W), India

*Corresponding author: Snehasis Jana, Trivedi Science Research Laboratory Pvt. Ltd., Thane (W), Maharashtra, India, Email: publication@trivedieffect.com

\section{Research Article \\ Volume 3 Issue 2}

Received Date: June 25, 2019

Published Date: August 02, 2019

DOI: $10.23880 /$ phoa- 16000140

\section{Abstract}

Zinc chloride is commonly used as a source of zinc for the treatment of many diseases and overall maintenance of good health. The impacts of the Trivedi Effect ${ }^{\circledR}$ on the physicochemical, thermal, and behavioral properties of zinc chloride were evaluated using sophisticated analytical techniques. Zinc chloride was divided into control and treated parts. Only, the treated part received the Trivedi Effect ${ }^{\circledR}$-Consciousness Energy Healing Treatment remotely by a renowned Biofield Energy Healer, Dahryn Trivedi. The powder XRD relative peak intensities and crystallite sizes of the treated zinc chloride were significantly altered ranging from -58.73 to 141.43 and -74.03 to $228.56 \%$, respectively compared with the control sample. The average crystallite size of the treated zinc chloride was significantly increased by $4.34 \%$ compared with the control sample. The particle sizes of the treated zinc chloride sample were significantly altered by $11.04 \%\left(\mathrm{~d}_{10}\right),-11.85 \%$ $\left(d_{50}\right),-20.35 \%\left(d_{90}\right)$, and $-21.88 \%\{D(4,3)\}$ compared with the control sample. Thus, the surface area of the treated zinc chloride $\left(10400 \mathrm{~m}^{2} / \mathrm{g}\right)$ was significantly increased by $112.24 \%$ compared with the control sample $\left(4900 \mathrm{~m}^{2} / \mathrm{g}\right)$. The latent heat of fusion and decomposition of the treated sample were significantly increased by $96.18 \%$ and $134.66 \%$, respectively compared with the control sample. The current study predicted that the Trivedi Effect ${ }^{\circledR}$-Consciousness Energy Healing Treatment might produce a new polymorphic form of zinc chloride with larger crystallite size, smaller particle size, and increased surface area, which would improve the solubility, absorption, bioavailability, and thermal stability compared with the control sample. Therefore, the Consciousness Energy Healing Treated zinc chloride would be very useful to design more efficacious nutraceutical or pharmaceutical formulations for the treatment of immunological disorders, inflammatory diseases, aging, stress, cancer, parakeratosis, dysosmia, hypogonadism, Wilson's disease, anorexia, etc.

Keywords: Consciousness Energy Healing Treatment; The Trivedi Effect ${ }^{\circledR}$; Zinc Chloride; Powder XRD; Particle Size; Surface Area; Latent Heat 
Abbreviations: PXRD: Powder X-ray Diffraction; PSD: Particle Size Distribution; DSC: Differential Scanning Calorimetry; CAM: Complementary and Alternative Medicine; NCCIH: National Center of Complementary and Integrative Health.

\section{Introduction}

Zinc is of the essential trace element which regulates a broad spectrum of physiological functions in the human body [1]. Zinc is plenty available in animal meat, eggs, fish, fowl, milk, wheat, and various seeds like poppy, sesame, mustard, alfalfa, celery, nuts, beans, almonds, pumpkin seeds, sunflower seeds, whole grains, and blackcurrant [2,3]. It is available in more than 100 enzymes (i.e., carboxypeptidase, carbonic anhydrase, etc.) and protein (i.e., metallothioneins), coordinate amino acid chains, act like a structural ion in nucleic acid and protein metabolism, transcription factors, etc [4-7]. It enhances fertility, protects the retina, modulates immune, antioxidant, and assumed antiviral in the body $[6,8]$. It increases the leukocyte count and phagocytic index in combination with other nutraceuticals [9]. It is also used to prevent many deficiency disorders include hypogeusia, dysosmia, anorexia, parakeratosis, geophagia, hypogonadism, growth retardation, Wilson's disease, etc [10-13]. Deficiency of zinc is due to inadequate dietary intake, malabsorption, chronic renal and liver disease, sickle cell disease, acrodermatitis enteropathica, diabetes, malignancyand, etc [14].

Zinc chloride is a very common source for zinc, used in the nutraceutical, pharmaceutical, and cosmetic industry for the preparation of the drug, diagnostic agent, desensitizer, mouth-wash, dentin disinfectant, deodorant, protein precipitator and insulin preparation [15-18]. It is also used for the treatment of skin cancer and canine and malignant skin wounds $[19,20]$. Therefore, it was considered as one of the ingredients in the nutraceuticals/pharmaceuticals supplement for the prevention and treatment of various disorders. It is also used in the chemicals, textile, metallurgy, and paper manufacturing industry [17]. Zinc chloride is irritant to skin, occasionally leading to hematemesis, caustic to the gastrointestinal tract, lethal at the dose of $3-5 \mathrm{mg}$ to human, and very harmful to the pulmonary and lungs on exposure to zinc chloride smoke $[17,21]$.

Physicochemical properties of nutraceutical and pharmaceutical compounds are very important for better bioavailability and therapeutic efficacy. Physicochemical properties of many pharmaceutical/nutraceutical compounds reported being significantly altered by means of the Trivedi Effect ${ }^{\circledR}$-Consciousness Energy Healing Treatment, along with enhanced the bioavailability of poorly bioavailable pharmaceutical/ nutraceutical compounds [22-27]. The Trivedi Effect ${ }^{\circledR}$ is a scientifically proven phenomenon in which an individual can harness this intelligent energy from the universe and transfer it anywhere on the planet via the possible mediation of neutrinos [28-30]. The Biofield is infinite, paradimensional and dynamic electromagnetic field exists surrounding the human body [31,32]. Biofield based Energy Healing Therapies accepted worldwide for the use against various human disease conditions and has been accepted as a Complementary and Alternative Medicine (CAM) health care approach by the National Center of Complementary and Integrative Health (NCCIH) along with Tai Chi, Reiki, hypnotherapy, Ayurvedic medicine, yoga, Qi Gong, aromatherapy, meditation, traditional Chinese herbs and medicines, homeopathy, chiropractic/osteopathic manipulation, acupuncture, acupressure, naturopathy, cranial sacral therapy, movement therapy, etc [31-33]. Biofield Energy Treatment has also been reported in many peer-reviewed scientific journals with significant outcomes in microbiology, biotechnology, medical research, and agricultural science [34-42]. The physicochemical properties of a drug have a vital role in the drug during processing, formulation, packaging, and storage $[43,44]$. In this study, the influence of the Trivedi Effect ${ }^{\circledR}$ on the properties of zinc chloride was evaluated using sophisticated analytical techniques.

\section{Materials and Methods}

\section{Chemicals and Reagents}

The test sample zinc chloride powder was procured from Tokyo Chemical Industry Co., Ltd., Japan and the additional chemicals were purchased in India.

\section{Consciousness Energy Healing Treatment Strategies}

The test sample zinc chloride was equally divided into two parts. One part of the zinc chloride did not receive the Trivedi Effect ${ }^{\circledR}$-Consciousness Energy Healing Treatment and named as the control zinc chloride sample. But, the control zinc chloride was treated with a "sham" healer, who did not have any knowledge about the Consciousness Energy Healing Treatment. The other part of the zinc chloride was treated with the Consciousness Energy Healing Treatment by a renowned Biofield Energy Healer, Dahryn Trivedi, USA remotely under standard laboratory 
conditions (3 minutes) and named as treated zinc chloride. After that, the treatment both the samples were kept in similar sealed conditions and further characterized using different analytical techniques.

\section{Characterization}

The powder X-ray diffraction (PXRD) analysis of zinc chloride powder samples was performed with the help of PANalytical X'Pert3 powder X-ray diffractometer, UK $[45,46]$. The average size of crystallites was calculated using the Scherrer's formula (1)

$$
\mathrm{G}=\mathrm{k} \lambda / \beta \cos \theta
$$

Where, G: crystallite size, $\lambda$ : radiation wavelength, $\mathrm{k}$ : equipment constant, $\beta$ : full-width half maximum, and $\theta$ : Bragg angle [47].

The particle size distribution (PSD) analysis of the zinc chloride was performed using Malvern Mastersizer 3000, UK using the wet method. Similarly, the differential scanning calorimetry (DSC) analysis of zinc chloride was performed with the help of DSC Q200, TA instruments $[45,46]$.
The $\%$ change in the parameters in the treated zinc chloride was calculated compared to the control sample using the following equation 2 :

$$
\% \text { Change }=\frac{[\text { Treated }- \text { Control }]}{\text { Control }} \times 100(2)
$$

\section{Results and Discussion}

\section{Powder X-ray Diffraction (PXRD) Analysis}

The PXRD diffractograms of both the zinc chloride are shown in Figure 1. The samples displayed sharp and intense peaks in their respective diffractograms indicated that both the samples were crystalline nature. Both the PXRD diffractograms showed greater intensity $(100 \%)$ at Bragg's angle $(2 \theta)$ equal to $25.6^{\circ}$ (Table 1 , entry 9). The relative PXRD peak intensities of the treated zinc chloride were significantly altered in the range from -58.73 to 141.43 compared with the control sample (Table 1). Therefore, the crystallite sizes of the Biofield Energy Treated zinc chloride were significantly altered in the range from -74.03 to $228.56 \%$ compared to the control sample. But, the average crystallite size of the treated zinc chloride was increased by $4.34 \%$ (Table 1, entry 40 ) compared to the control sample.

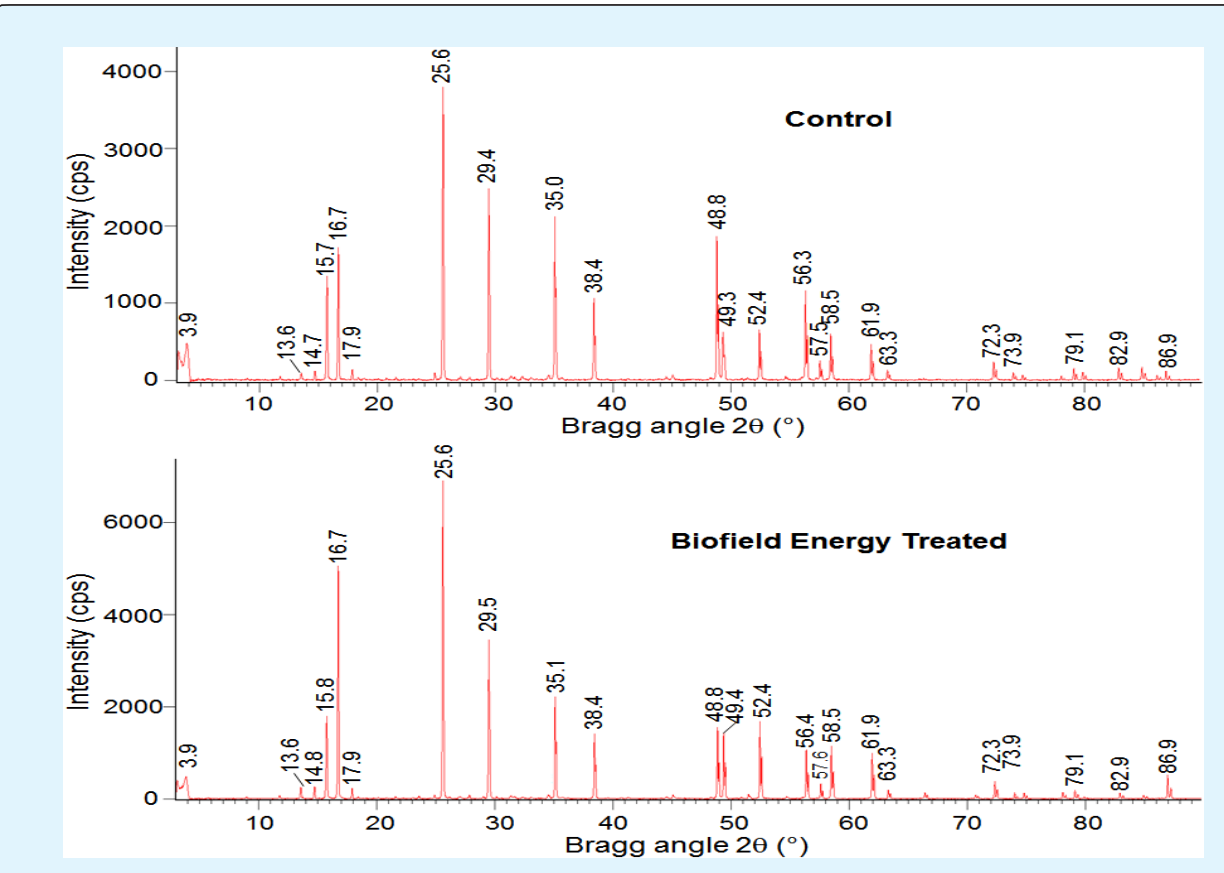

Figure 1: Powder XRD diffractograms of the control and treated zinc chloride. 


\begin{tabular}{|c|c|c|c|c|c|c|c|}
\hline \multirow{2}{*}{ Entry No. } & \multirow{2}{*}{ Bragg angle $\left({ }^{\circ} 2 \theta\right)$} & \multicolumn{3}{|c|}{ Relative Intensity (\%) } & \multicolumn{3}{|c|}{ Crystallite Size(G, nm) } \\
\hline & & Control & Treated & $\%$ Change & Control & Treated & $\%$ Change \\
\hline 1 & 3.9 & 12.47 & 7.17 & -42.5 & 21.56 & 17.26 & -19.98 \\
\hline 3 & 13.6 & 2.38 & 3.74 & 57.14 & 34.74 & 49.7 & 43.09 \\
\hline 4 & 14.8 & 3.17 & 3.83 & 20.82 & 38.65 & 43.54 & 12.65 \\
\hline 5 & 15.8 & 35.87 & 26.74 & -25.45 & 43.54 & 49.82 & 14.44 \\
\hline 6 & 16.7 & 46.33 & 75.72 & 63.44 & 38.74 & 43.66 & 12.7 \\
\hline 7 & 17.9 & 3.47 & 3.29 & -5.19 & 34.92 & 44.16 & 26.48 \\
\hline 8 & 24.9 & 2.51 & 1.14 & -54.58 & 35.32 & 50.55 & 43.11 \\
\hline 9 & 25.6 & 100 & 100 & 0 & 50.55 & 58.49 & 15.71 \\
\hline 10 & 29.5 & 65.7 & 51.43 & -21.72 & 71.27 & 18.51 & -74.03 \\
\hline 11 & 34.6 & 1.69 & 1.12 & -33.73 & 22.57 & 74.15 & 228.56 \\
\hline 12 & 35.1 & 56.4 & 33.18 & -41.17 & 74.14 & 98.9 & 33.39 \\
\hline 13 & 35.2 & 30.26 & 17.62 & -41.77 & 98.88 & 59.9 & -39.43 \\
\hline 14 & 38.4 & 28.4 & 20.96 & -26.2 & 59.89 & 99.86 & 66.76 \\
\hline 15 & 38.5 & 14.55 & 10.53 & -27.63 & 74.88 & 62.12 & -17.05 \\
\hline 16 & 48.8 & 49.77 & 23.16 & -53.47 & 62.11 & 62.15 & 0.07 \\
\hline 17 & 48.9 & 26.09 & 11.73 & -55.04 & 62.14 & 62.25 & 0.18 \\
\hline 18 & 49.4 & 16.55 & 21.39 & 29.24 & 44.45 & 52.54 & 18.2 \\
\hline 19 & 52.4 & 17.52 & 25.25 & 44.12 & 63.04 & 63.09 & 0.08 \\
\hline 20 & 52.6 & 9.89 & 13.52 & 36.7 & 63.08 & 64.17 & 1.73 \\
\hline 21 & 56.4 & 30.94 & 16.05 & -48.13 & 53.46 & 64.22 & 20.11 \\
\hline 22 & 56.5 & 15.36 & 8.63 & -43.82 & 53.5 & 64.54 & 20.63 \\
\hline 23 & 57.6 & 6.63 & 4.77 & -28.05 & 53.77 & 64.59 & 20.12 \\
\hline 24 & 57.7 & 3.52 & 2.57 & -26.99 & 64.58 & 54.02 & -16.35 \\
\hline 25 & 58.5 & 15.92 & 17.07 & 7.22 & 64.81 & 54.06 & -16.58 \\
\hline 26 & 58.6 & 8.06 & 8.9 & 10.42 & 64.87 & 54.97 & -15.26 \\
\hline 27 & 61.9 & 12.33 & 14.86 & 20.52 & 47.1 & 47.16 & 0.12 \\
\hline 28 & 62.1 & 6.45 & 7.76 & 20.31 & 55.01 & 47.45 & -13.73 \\
\hline 29 & 63.3 & 3.43 & 2.81 & -18.08 & 55.36 & 58.38 & 5.46 \\
\hline 30 & 72.3 & 6.32 & 5.63 & -10.92 & 50.03 & 50.1 & 0.15 \\
\hline 31 & 72.5 & 3.69 & 2.9 & -21.41 & 58.44 & 59.01 & 0.98 \\
\hline 32 & 73.9 & 2.61 & 1.97 & -24.52 & 59 & 59.32 & 0.56 \\
\hline 33 & 74.8 & 1.61 & 1.79 & 11.18 & 44.48 & 60.68 & 36.41 \\
\hline 34 & 78.1 & 1.47 & 2.05 & 39.46 & 60.66 & 52.39 & -13.64 \\
\hline 35 & 79.1 & 4.15 & 2.85 & -31.33 & 61.12 & 45.93 & -24.86 \\
\hline 36 & 79.3 & 2.11 & 1.32 & -37.44 & 45.92 & 62.89 & 36.95 \\
\hline 37 & 82.9 & 4.4 & 1.82 & -58.64 & 62.88 & 47.26 & -24.84 \\
\hline 38 & 83.4 & 2.52 & 1.04 & -58.73 & 47.25 & 77.85 & 64.75 \\
\hline 39 & 86.9 & 3.21 & 7.75 & 141.43 & 77.91 & 65.09 & -16.46 \\
\hline 40 & & e crystalli & size & & 54.59 & 56.97 & 4.34 \\
\hline
\end{tabular}

Table 1: Powder XRD data of the control and treated zinc chloride.

It can be assumed from the results that the relative peak intensities and crystal sizes were significantly altered due to the Trivedi Effect ${ }^{\circledR}$-Consciousness Energy Healing Treatment. As per the literature, any changes in the PXRD patterns, such as relative intensities and crystallite size, indicated the change in the crystal morphology as well as the proof of polymorphic transition
[48-50]. The crystal pattern, size, and even polymorphic form play important roles in drug solubility, dissolution, and bioavailability of orally administered pharmaceutical/nutraceutical [43]. Therefore, the Trivedi Effect ${ }^{\circledR}$-Consciousness Energy Healing Treated zinc chloride could be very useful for designing more effective nutraceutical or pharmaceutical formulations. 


\section{Particle Size Distribution (PSD) Analysis}

The particle size values and the average surface area of both the zinc chloride samples were evaluated (Table 2). The particle sizes of the Biofield Energy Treated zinc chloride sample were significantly altered by $11.04 \%$ $\left(d_{10}\right),-11.85 \%\left(d_{50}\right),-20.35 \%\left(d_{90}\right)$, and $-21.88 \%\{D(4,3)\}$ compared with the control sample. The surface area of the treated zinc chloride $\left(10400 \mathrm{~m}^{2} / \mathrm{g}\right)$ was significantly increased by $112.24 \%$ compared with the control zinc chloride sample $\left(4900 \mathrm{~m}^{2} / \mathrm{g}\right)$.

\begin{tabular}{|c|c|c|c|c|c|}
\hline Parameter & $\mathbf{d}_{\mathbf{1 0}}(\boldsymbol{\mu m})$ & $\mathbf{d}_{\mathbf{5 0}}(\boldsymbol{\mu} \mathbf{m})$ & $\mathbf{d}_{\mathbf{9 0}}(\boldsymbol{\mu m})$ & $\mathbf{D}(\mathbf{4}, \mathbf{3}) \mathbf{( \mu m )}$ & Surface area $\left(\mathbf{m}^{\mathbf{2}} / \mathbf{g}\right)$ \\
\hline Control & 36.24 & 96.73 & 191.01 & 114.69 & 4900 \\
\hline Biofield Energy Treated & 40.24 & 85.27 & 152.13 & 89.6 & 10400 \\
\hline Percent change (\%) & 11.04 & -11.85 & -20.35 & -21.88 & 112.24 \\
\hline
\end{tabular}

$\mathrm{d}_{10}, \mathrm{~d}_{50}$, and $\mathrm{d}_{90}$ : particle diameter corresponding to $10 \%, 50 \%$, and $90 \%$ of the cumulative distribution, $\mathrm{D}(4,3)$ : the average mass-volume diameter, and SSA: the specific surface area.

Table 2: Particle size data and surface area of the control and treated samples.

As per the literature reports, the reduced particle size and increased surface area of any pharmaceutical compound improve its dissolution rate, absorption, and bioavailability $[43,44,51]$. From the results, it can be assumed that the introduction of the external force like the Trivedi Effect ${ }^{\circledR}$-Biofield Energy Treatment transformed the larger size zinc chloride particles into smaller particles. Therefore, Biofield Energy Healing Treated zinc chloride might offer better solubility, absorption, and bioavailability in the body compared to the control sample.

\section{Differential Scanning Calorimetry (DSC) Analysis}

The DSC thermograms of both the control and Biofield Energy Treated zinc chloride are shown in Figure 2. The thermal analysis data such as melting/decomposition temperature and enthalpy of fusion/decomposition of the control and Biofield Energy Treated zinc chloride were calculated (Table 3). The melting temperature of the Biofield Energy Treated zinc chloride $\left(315.04^{\circ} \mathrm{C}\right)$ was very close compared with the control sample $\left(316.62^{\circ} \mathrm{C}\right)$. Similarly, the decomposition temperature of the treated zinc chloride was similar to the control sample. The latent heat of fusion or enthalpy of fusion $\left(\Delta \mathrm{H}_{\text {fusion }}\right)$ of the control and Biofield Energy Treated zinc chloride was $27.48 \mathrm{~J} / \mathrm{g}$ and $53.91 \mathrm{~J} / \mathrm{g}$, respectively. Therefore, the $\Delta \mathrm{H}_{\text {fusion }}$ of the Biofield Energy Treated sample was significantly increased by $96.18 \%$ compared with the control sample. Similarly, the enthalpy of decomposition $\left(\Delta \mathrm{H}_{\text {decomposition }}\right)$ of the control and Biofield Energy Treated zinc chloride was $19.56 \mathrm{~J} / \mathrm{g}$ and $45.90 \mathrm{~J} / \mathrm{g}$, respectively. The $\Delta \mathrm{H}_{\text {decomposition }}$ of the Biofield Energy Treated sample was significantly increased by $134.66 \%$ compared with the control sample. Overall, the thermal stability of the Biofield Energy Treated zinc chloride was significantly increased and needs more energy to undergo the process of melting after the Trivedi Effect ${ }^{\circledR}$-Biofield Energy Treatment. The thermal stability of the pharmaceuticals and nutraceuticals are very important [52]. Therefore, improved thermal properties will helpful for long-term storage stability of the treated zinc chloride.

\begin{tabular}{|c|c|c|c|}
\hline Peak & Sample & $\mathbf{T}\left({ }^{\circ} \mathbf{C}\right)$ & $\mathbf{\Delta H}(\mathbf{J} / \mathbf{g})$ \\
\hline \multirow{3}{*}{ Endothermic peak } & Control sample & 316.62 & 27.48 \\
\cline { 2 - 4 } & Biofield Energy Treated sample & 315.04 & 53.91 \\
\cline { 2 - 4 } & \% Change & -0.5 & 96.18 \\
\hline \multirow{3}{*}{ Exothermic peak } & Control sample & 383.19 & 19.56 \\
\cline { 2 - 4 } & Biofield Energy Treated sample & 383.42 & 45.9 \\
\cline { 2 - 4 } & \% Change & 0.06 & 134.66 \\
\hline
\end{tabular}

T: melting/decomposition temperature, $\Delta \mathrm{H}$ : Enthalpy of fusion/decomposition.

Table 3: The latent heat of fusion $(\mathrm{J} / \mathrm{g})$, enthalpy of decomposition $(\mathrm{J} / \mathrm{g})$ and melting/decomposition temperature $\left({ }^{\circ} \mathrm{C}\right)$ values of the control and treated zinc chloride. 

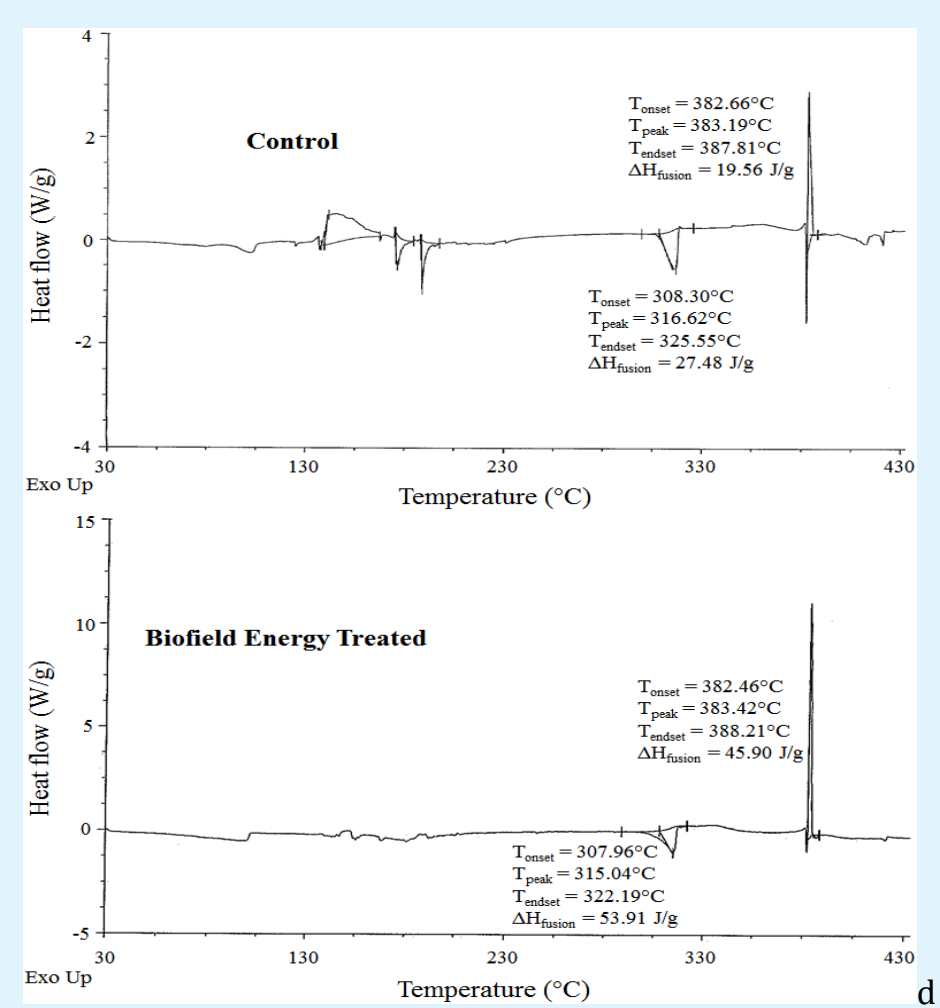

Figure 2: DSC thermograms of the control and Biofield Energy Treated zinc chloride.

\section{Conclusion}

The current study results revealed that the Trivedi Effect ${ }^{\circledR}$-Consciousness Energy Healing Treatment has a significant influence on the physicochemical properties of zinc chloride. The powder XRD peak intensities and crystallite sizes of the treated zinc chloride were significantly altered ranging from -58.73 to 141.43 and 74.03 to $228.56 \%$, respectively compared with the control sample. However, the average crystallite size of the treated sample was significantly increased by $4.34 \%$ compared with the control sample. The particle sizes of the Biofield Energy Treated zinc chloride sample were significantly altered by $11.04 \%\left(\mathrm{~d}_{10}\right),-11.85 \%\left(\mathrm{~d}_{50}\right)$, $20.35 \%\left(\mathrm{~d}_{90}\right)$, and $-21.88 \%\{\mathrm{D}(4,3)\}$ compared with the control sample. Thus, the surface area of the treated zinc chloride was considerably increased by $112.24 \%$ compared with the control sample. The latent heat of fusion and decomposition of the Biofield Energy Treated sample were significantly increased by $96.18 \%$ and $134.66 \%$, respectively compared with the control sample. The current study predicted that the Trivedi Effect ${ }^{\circledR}$ Consciousness Energy Healing Treatment might produce a new polymorphic form of zinc chloride with larger crystallite size, smaller particle size, and increased surface area, which would improve the solubility, absorption, bioavailability, and thermal stability compared with the control sample. Therefore, the Consciousness Energy Healing Treated zinc chloride would be very useful to design novel and more efficacious nutraceutical or pharmaceutical formulations for the better therapeutic response against immunological disorders, inflammatory diseases, aging, stress, cancer, parakeratosis, hypogeusia, dysosmia, hypogonadism, Wilson's disease, anorexia, etc.

\section{References}

1. Hambidge KM, Krebs NF (2007) Zinc deficiency: A special challenge. J Nutr 137(4): 1101-1105.

2. Ensminger AH, Konlande JE (1993) Foods \& Nutrition Encyclopedia, $2^{\text {nd }}(E d n),. C R C$ Press, Boca Raton, Florida, pp: 2368-2369.

3. USDA (2017) Zinc content of selected foods per common measure. USDA National Nutrient Database for Standard Reference, United States Department of Agriculture. 
4. Plum LM, Rink L, Haase H (2010) The essential toxin: Impact of zinc on human health. Int J Environ Res Public Health 7(4): 1342-1365.

5. Erik GB, Mikko H, Tore B, Tomas B, Olle E (2009) Molecular dynamics study of zinc binding to cysteines in a peptide mimic of the alcohol dehydrogenase structural zinc site. Phys Chem Chem Phys 11: 975983.

6. Ronconi L, Sadler PJ (2008) Applications of heteronuclear NMR spectroscopy in biological and medicinal inorganic chemistry. Coordn Chem Rev 252(21-22): 2239-2277.

7. Berg JM, Shi Y (1996) The galvanization of biology: A growing appreciation for the roles of zinc. Science 271(5252): 1081-1085.

8. Higdon JV, Ho E (2005) Metallotherapeutic drugs and metal-based diagnostic agents: The use of metals in medicine. In: Gielen M, Tiekink ERT, (Eds.), WileyVCH, Weinheim, pp: 237.

9. Mazumder PM, Pattnayak S, Parvani H, Sasmal D, Rathinavelusamy P (2012) Evaluation of immunomodulatory activity of Glycyrhiza glabra L. roots in combination with zing. Asian Pac J Trop Biomed 2(1): S15-S20.

10. Brewer GJ (2001) Zinc acetate for the treatment of Wilson's disease. Expert Opin Pharmacother 2(9): 1473-1477.

11. Prasad AS (1979) Clinical, biochemical, and pharmacological role of zinc. Ann Rev Pharmacol Toxicol 19: 393-426.

12. Supuran CT (2008) Carbonic anhydrases: Novel therapeutic applications for inhibitors and activators. Nat Rev Drug Dis 7(2): 168-181.

13. Elmes ME (1975) Letter: Zinc in human medicine. Lancet 2(7934): 549.

14. Prasad AS (2003) Zinc deficiency: Has been known of for 40 years but ignored by global health organisations. BMJ 326(7386): 409-410.

15. Brynestad J, Yakel HL (1978) Preparation and structure of anhydrous zinc chloride. Inorg Chem 17: 1376-1377.
16. Kasture AV, Wadodkar SG (2008) A text book of pharmaceutical chemistry-1. Nirali Prakashan 25th (Edn.), Pune, India.

17. Mahadik KR, Kuchekar BS (2008) Concise inorganic pharmaceutical chemistry. Nirali Prakashan $25^{\text {th }}$ (Edn.), Pune, India.

18. McDaniel S, Goldman GD (2002) Consequences of using escharotic agents as primary treatment for nonmelanoma skin cancer. Arch Dermatol 138(12): 1593-1596.

19. Fukuyama Y, Kawarai S, Tezuka T, Kawabata A, Maruo T (2016) The palliative efficacy of modified Mohs paste for controlling canine and feline malignant skin wounds. Vet Q 36(3): 176-182.

20. Rohe DMM, Wolf HU (2007) Zinc Compounds, Ullmann's Encyclopedia of Industrial Chemistry (7th Edn.), Wiley, pp: 1-6.

21. Trivedi MK, Branton A, Trivedi D, Nayak G, Nykvist CD, et al. (2017) Evaluation of the Trivedi Effect $\AA$ Energy of Consciousness Energy Healing Treatment on the physical, spectral, and thermal properties of zinc chloride. American Journal of Life Sciences 5(1): 11-20.

22. Trivedi MK, Branton A, Trivedi D, Shettigar H, Bairwa $\mathrm{K}$, et al. (2015) Fourier Transform Infrared and Ultraviolet-Visible Spectroscopic Characterization of Biofield Treated Salicylic Acid and Sparfloxacin. Nat Prod Chem Res 3: 186.

23. Trivedi MK, Patil S, Shettigar H, Bairwa K, Jana S (2015) Spectroscopic characterization of biofield treated metronidazole and tinidazole. Med chem 5: 340-344.

24. Branton A, Jana S (2017) The influence of energy of consciousness healing treatment on low bioavailable resveratrol in male Sprague Dawley rats. International Journal of Clinical and Developmental Anatomy 3(3): 9-15.

25. Branton A, Jana S (2017) The use of novel and unique biofield energy healing treatment for the improvement of poorly bioavailable compound, berberine in male Sprague Dawley rats. American Journal of Clinical and Experimental Medicine 5(4): 138-144. 
26. Branton A, Jana S (2017) Effect of The biofield energy healing treatment on the pharmacokinetics of 25hydroxyvitamin D3 [25(OH)D3] in rats after a single oral dose of vitamin D3. American Journal of Pharmacology and Phytotherapy 2(1): 11-18.

27. Trivedi MK, Mohan TRR (2016) Biofield energy signals, energy transmission and neutrinos. American Journal of Modern Physics 5(6): 172-176.

28. Rubik B, Muehsam D, Hammerschlag R, Jain S (2015) Biofield science and healing: history, terminology, and concepts. Glob Adv Health Med 4(S1): 8-14.

29. Warber SL, Cornelio D, Straughn J, Kile G (2004) Biofield energy healing from the inside. J Altern Complement Med 10(6): 1107-1113.

30. Movaffaghi Z, Farsi M (2009) Biofield therapies: Biophysical basis and biological regulations? Complement Ther Clin Pr 15(1): 35-37.

31. Barnes PM, Bloom B, Nahin RL (2008) Complementary and alternative medicine use among adults and children: United States, 2007. Natl Health Stat Report 10(12): 1-23.

32. Koithan M (2009) Introducing complementary and alternative therapies. J Nurse Pract 5(1): 18-20.

33. Trivedi MK, Patil S, Shettigar H, Bairwa K, Jana $S$ (2015) Phenotypic and biotypic characterization of Klebsiella oxytoca: An impact of biofield treatment. J Microb Biochem Technol 7: 203-206.

34. Trivedi MK, Patil S, Shettigar H, Gangwar M, Jana S (2015) An effect of biofield treatment on multidrugresistant Burkholderia cepacia: A multihost pathogen. J Trop Dis 3: 167.

35. Trivedi MK, Patil S, Shettigar H, Gangwar M, Jana S (2015) In vitro evaluation of biofield treatment on cancer biomarkers involved in endometrial and prostate cancer cell lines. J Cancer Sci Ther 7: 253257.

36. Trivedi MK, Branton A, Trivedi D, Nayak G (2015) Evaluation of plant growth regulator, immunity and DNA fingerprinting of biofield energy treated mustard seeds (Brassica juncea). Agriculture, Forestry and Fisheries 4: 269-274.
37. Trivedi MK, Patil S, Shettigar H, Mondal SC, Jana S (2015) The potential impact of biofield treatment on human brain tumor cells: A time-lapse video microscopy. J Integr Oncol 4(3): 141.

38. Trivedi MK, Tallapragada RM, Branton A, Trivedi D, Nayak G, et al. (2015) The potential impact of biofield energy treatment on the physical and thermal properties of silver oxide powder. International Journal of Biomedical Science and Engineering 3: 6268.

39. Trivedi MK, Tallapragada RM, Branton A, Trivedi D, Nayak G, et al. (2015) Analysis of physical, thermal, and structural properties of biofield energy treated molybdenum dioxide. International Journal of Materials Science and Applications 4: 354-359.

40. Trivedi MK, Branton A, Trivedi D, Nayak G, Latiyal O, et al. (2015) Evaluation of biofield treatment on atomic and thermal properties of ethanol. Organic Chem Curr Res 4: 145.

41. Trivedi MK, Branton A, Trivedi D, Nayak G, Gangwar M, et al. (2015) Agronomic characteristics, growth analysis, and yield response of biofield treated mustard, cowpea, horse gram, and groundnuts. International Journal of Genetics and Genomics 3: 7480.

42. Blagden N, de Matas M, Gavan PT, York P (2007) Crystal engineering of active pharmaceutical ingredients to improve solubility and dissolution rates. Adv Drug Deliv Rev 59(7): 617-630.

43. Chereson R (2009) Bioavailability, bioequivalence, and drug selection. In: Makoid CM, Vuchetich PJ, Banakar UV, (Eds.), Basic pharmacokinetics, $1^{\text {st }}$ (Edn.), Pharmaceutical Press, London.

44. Trivedi MK, Sethi KK, Panda P, Jana S (2017) A comprehensive physicochemical, thermal, and spectroscopic characterization of zinc (II) chloride using X-ray diffraction, particle size distribution, differential scanning calorimetry, thermogravimetric analysis/differential thermogravimetric analysis, ultraviolet-visible, and Fourier transform-infrared spectroscopy. International Journal of Pharmaceutical Investigation 7(1): 33-40.

45. Trivedi MK, Sethi KK, Panda P, Jana S (2017) Physicochemical, thermal and spectroscopic characterization of sodium selenate using XRD, PSD, 
DSC, TGA/DTG, UV-vis, and FT-IR. Marmara Pharmaceutical Journal 21(2): 311-318.

46. Langford JI, Wilson AJC (1978) Scherrer after sixty years: A survey and some new results in the determination of crystallite size. J Appl Cryst 11: 102113.

47. Raza K, Kumar P, Ratan S, Malik R, Arora S (2014) Polymorphism: The phenomenon affecting the performance of drugs. SOJ Pharm Pharm Sci 1(2): 10.

48. Brittain HG (2009) Polymorphism in pharmaceutical solids in Drugs and Pharmaceutical Sciences. Informa Healthcare USA, Inc., New York.
49. Thiruvengadam E, Vellaisamy G (2014) Polymorphism in pharmaceutical ingredients a review. World Journal of Pharmacy and Pharmaceutical Sciences 3(3): 621-633.

50. Mosharrof M, Nystrom C (1995) The effect of particle size and shape on the surface specific dissolution rate of microsized practically insoluble drugs. Int J Pharm 122: 35-47.

51. Giron D (2002) Applications of thermal analysis and coupled techniques in the pharmaceutical industry. J Thermal Anal 68(2): 335-357. 